\title{
REPORT REVIEW
}

\section{The Importance of Agriculture for Development: A Review Article on the Role of Agriculture in Economic and Social Development Based on the Human Development of South Asia Report 2002}

\author{
Nimal Sanderatne ${ }^{1}$
}

The Human Development of South Asia 2002 Report is of special interest to agricultural economists as it more or less redefines the role of agriculture in development. It argues the case for continued development of agriculture as the only means by which poverty and human degradation could be reduced. The message of the Report is strong and clear. "high levels of human development cannot be achieved if development priorities do not focus on the occupation of the people - both farm and non farm - and where they live rural areas."

The significance of the Human Development of South Asia 2002 Report is that it focuses on agricultural and rural development as the means by which human development could be achieved in South Asia. It analyses the reasons for the persistence of poverty, poor human development indicators and the inability to raise the poor from their misery and comes to the conclusion that without agricultural and rural development the causes of poor human development indicators cannot be eradicated. It is strongly of the view that the economic development strategies adopted in recent decades by South Asian countries were unable to reduce poverty and household level food security owing to inadequate growth in agriculture. Although promoting economic growth and even increases in agricultural and food production, they were incapable of promoting the welfare of a sizeable proportion of the population. The report is of the view that poverty, hunger, malnutrition and the poor human development indicators that are largely a rural phenomenon cannot be resolved by mere overall economic growth, though overall growth is indeed vital. It argues for a new thrust in agricultural development that alone can address these issues. This thrust requires more resources into research, an effective linkage in research and extension and more effective marketing channels for agricultural produce. In other words it argues for a much stronger institutional support for agriculture. what has to be done in Sri

1 Senior Visiting Fellow, Post Graduate Institute of Agriculture, University of Peradeniya 
Lanka is no different. Sri Lanka's agricultural performance, particularly in the food crops, has been very inadequate. While in South Asia agriculture grew at an average of 3 per cent, it was below 3 per cent in Sri Lanka. The slide continued in 2000 and 2001. In 2003 agricultural growth was only 1.5 per cent despite increased paddy production. In 2004 food crop agriculture is performing badly owing to drought conditions. This is a fundamental reason for the persistence of poverty in rural areas. It must be admitted that tardy economic growth in other areas of the economy also failed to provide a beneficial impact. The absorption of labour and new employment opportunities in industry and services were limited. In fact the situation would have been much worse if not for the release of labour into occupations in the Middle East and the remittances from these countries. The income from soldiers and Samurdhi would have also boosted rural incomes. That agricultural growth was inadequate to sustain rural incomes and employment is indeed very clear. It is also clear that the institutional support for rural agriculture was woefully inadequate and has perhaps deteriorated. The same requisites for agricultural development that South Asia needs are the need for our agriculture as well. These include improved institutional infrastructure, more resources for agricultural research and extension that should be coupled, improvements in pricing policy and marketing, reforms in land policies and a number of other areas to support small farm agriculture.

The fundamental issue is this. An economic strategy that focuses on the development of industry and services may generate economic growth. Such growth can assist in increasing employment and incomes and reducing poverty, yet its impact is likely to be limited. As in the case of South Asia in general, the employment opportunities in industry would be inadequate to absorb the increases in the numbers entering the labour force annually. The country's per capita income would rise, but poverty in rural areas would remain high. It is not a case of either industry or agriculture, but a balanced and forceful thrust in all sectors of the economy without neglecting agriculture. Sri Lanka has achieved fairly good human development indicators owing to the welfare measures in the past. Now these must be improved through sustained rapid economic growth, especially agricultural development.

While overall economic growth and diversification are important factors in ensuring national food security, agricultural development has a vital role to play in ensuring food availability at household level. Increased agricultural production by improving incomes of rural households could enhance household access to food considerably, as a large proportion of the country's population is dependent on agricultural incomes, directly or in directly. The 
improvement of agricultural productivity through technological change is an essential strategy in achieving the right to food of a significantly large proportion of the population.

Agricultural policy and performance has an important bearing on household food availability, both directly and indirectly. Since about one half of the country's households are rural and derive incomes from agricultural activity, the level of agricultural production, the productivity of crops, the cost structures of agricultural production, land tenure systems and prices of agricultural produce have an important bearing on the capacity of a sizeable proportion of households to be food secure. In Amartya Sen's terminology, these conditions in agricultural production affect the "entitlements" of farm and rural households. Increases in agricultural production, especially an increase in agricultural productivity, would enhance food availability of rural and poor households. There lies a strong logic for a sustained thrust in agricultural production, not because of national food security concerns, but the capacity of rural households to access food.

Mellor and Adams have pointed this out in their paper "The New Political Economy of Food and Agricultural Development". In their words: Shipping food from more developed 'surplus' countries to still developing 'deficit' countries might seem to represent the easiest solution to the world's food problem. Such a simple-minded solution would, however, neglect one very important factor, namely the lack of purchasing power in many Third World countries. In this context it becomes advisable for many developing countries to place a far greater emphasis on agriculture than they have in the past. In most cases increased agricultural production can play several important roles in the development process. First, it can help increase overall domestic food supplies. Second, it can boost overall rates of economic growth. Third, as part of accelerated growth, it can help increase the poor's access to expand food supplies. Accelerated agricultural growth increases the income and employment opportunities of rural producers. This is important - in as much as the bulk of the rural population in many developing countries lives in the rural sector. Expanded opportunities for these people therefore help to facilitate broad-based employment and income growth in other sectors of the economy (Mellor and Adams, 1986).

Increased agricultural production means improved food availability to about one-half of our population either directly or indirectly. Directly farm households would have more income, especially the subsistence farm house holds. Indirectly farm households would have greater access to food through 
increased incomes or "entitlements". Other poor rural households would have a better access to food because of the likelihood of lower prices.

A strategy to enhance agricultural production is an equity approach to economic development and addresses the problem of household access to food more directly than through industrial development and exports. The latter strategies no doubt contribute to food security at the national level, but their contribution at household level could be more limited and certainly more indirect.

Mellor and Johnston in their paper, "The World Food Equation: Interrelation Among Development, Employment and Food Consumption" have argued that "Agricultural growth not only satisfies the need for food to meet nutritional requirements but fosters a favorable employment -oriented demand structure as well" (Mellor and Johnston, 1984). They have argued that in "the face of population growth and limited land area land augmenting technological change (is) essential to agriculture playing its productive role". (Ibid.) Their observation that "The employment - oriented effective demand is most likely to arise from a small holder agriculture, which is also fully consistent with high rates of technological change", is especially relevant to Sri Lanka at its present stage of agricultural development.

Increased agricultural production could be conceived of as an effective strategy for poverty alleviation, reduction in unemployment, increase in rural incomes and improvement in income distribution. All these improvements would enhance food availability. This is especially so as adequate alternate avenues of employment are not available in the country as a whole and in rural areas, in particular. Rhetoric on agricultural development has never been in short supply. It is meaningful and effective actions that are necessary. The recent bias against agriculture must be reversal if economic development is to be meaningful to the bulk of the country's population. There has always been controversy regarding the role of agriculture in economic development. This is more so after the impressive industrialization and economic growth in South East Asia in recent decades. The greater diversification of Asian economies, including those of Sri Lank, has added to a lesser credence in agriculture as an engine of growth. It urges governments to support small farm agriculture through pricing policies, infrastructure development, and increased resources for scientific research and linking such research with extension. Attempting to reduce poverty through welfare measures, it argues, is both expensive and ineffective. Despite a reasonable rate of economic growth in the 1990s, South Asia failed to reduce its poverty. In fact the number in poverty increased from 485 million to 530 million. About forty per 
cent of the World's poor live in South Asia. South Asia remains the poorest region in the world next to sub-Saharan Africa. Its social indicators have improved in the decade of the nineties, but they are deplorable. Nearly half (46 per cent) of the population of South Asia are illiterate and 200 million people are malnourished. Two thirds of the illiterate are women. Of every one thousand children 69 die before they reach 5 years. Nearly one half of the child population is malnourished, a large proportion of children in the region is underweight, stunted and wasted. As much as forty per cent of people in South Asia lack adequate food and are malnourished despite the bigger countries in the region having 70 million tons of wheat and rice in their go downs. Where human development indicators are concerned the Sri Lankan achievements are very different to those of most other South Asian countries except the Maldives. However, Sri Lanka's poverty level at 28 per cent of the population remains unacceptable. And poverty appears to be hopelessly intractable.

There is a heightened new interest in agriculture. Recent governments have acted as if agriculture is no longer of significance as it contributes only around 20 per cent of GDP. Other sectors of the economy are more glamorous and the future development of the country is expected to be through the development of industry and services. There can be no doubt that the nonagricultural sectors of the economy must grow to resolve many of the country's problems. Yet without a robust growth in agriculture, the country's economic growth would be dragged down, there would be strains on the trade balance and above all poverty would continue to be a significant problem. The fact is that agriculture has been neglected for nearly two decades. The argument for agricultural development must be tempered with realism. The capacity for agricultural growth in the region is restrained by inadequate irrigation, small size of farms and infrastructure bottlenecks that are very costly to remove. Besides this the annual increase in the labour force is of a magnitude that agriculture cannot absorb. Therefore the thrust in agricultural development must be viewed as an important component of the overall economic strategy with a significant role in human development without depreciating the importance of industrial development and high value-added services.

\section{References}

Human Development in South Asia, Agriculture and Rural Development. (2002). Pakistan:Oxford University Press. 
Mellor, J., and R.H. Adams. (1986). The New Political Economy of Food and Agricultural Development. Food Policy (November). New York:Harper and Row.289-290.

Mellor, John W., and Johnston, Bruce F. (1984). The World Food Equation. $J$. Econ. Lit. XXII(June):568. 